\title{
Vitamin C Supplementation to Growing Chick's Rations at Variable Temperature Levels
}

\author{
G.A.R. Kamar, M.A. Kicka, O.E. Mohamed and \\ M.M. El Shafei \\ Faculty of Agriculture and Veterinary College, Cairo \\ University, Giza, Egypt.
}

\begin{abstract}
THE Erfecer of supplementation of vitamin $\mathrm{C}$ to the diet of the 1 growing chicks reared under high, norm?l or low temperature, on the feed efficiency, growth rate mortality rate, serum calcium and phosphorus, body temperature, respiration rate and blood pressure een studied.

Rearing the growing chicks under high temperature $\left(90^{\circ} \mathrm{F}\right)$ for 12 weeks decreased the feed consumption and efficiency, bodyweight, relative growth rate and Serum clacium and phosphorus, while mortality rate was increased. Addition of ascorbic acid to the ration counteracting the depression effect of the heat stress caused an increase in feed consumption, feed efficiency, body weight relative growth rate, serum calcium and phosphorus and at the same time reduced the mortality rate.

High air temperature increased body temperature, respiration rate, and blood pressure. Supplemtntation of ascorbic acid decreased body tepmerature, while the respiration rate was inereased under high and normal tepmerature, and decreased under low temperature.
\end{abstract}

Vitamin C supplemeut did not affect blood pressure unoer the different temperature during the gowing peric $d^{\circ}$

Recently, the role of ascorbic acid in poultry physiology, nutrition and diseases has received considerable attention.

Reports in the literature on the influence of the addition of vitamin $\mathrm{C}$ to the growing chick ration are most contradictory, also the role of the environmental temperature has a significant effect. Thornton and Moreng (1958b) showed that supplementation of the ration with ascorbic acid did not affect body weight of S.C. White Leghorn pullets maintained under normal environmental conditions. Similar findings were reported by Gogus and Greminger (1959) and Thornton (1959b). Moreover, Subashandran and Balloun (1966) demonstrated that in heat stressed birds $\left(38^{\circ} \mathrm{C}\right)$ vitamin $\mathrm{C}$ was not effective in counteracting the weight depression. On the other hand, Thornton and Moreng (1958 b) found that the supplementation with ascorbic acid maintained the body weight of the pullets against the depression caused by 
increasing the environmental temperature to $80-82^{\circ} \mathrm{F}$. At the same time, Thornton $(1959 \mathrm{~b})$ proved that the presence of the vitamin $\mathrm{C}$ in the parental diet of Leghorn hens appeared to increase growth of chicks hatched from sumfound that this effect has not been observed during winter. Also the author found that the heavier chicks had a highly significant heavier ash weight;
he explained this by the effect on calcium metabolism.

Recently, Edrise (1973) demonstrated that dietary supplementation of 4 chicks $\mathrm{C}$ in a level of $100 \mathrm{mg}$ per $\mathrm{kg}$ diet increased the growth rate of Dokki 4 chicks reared under atmospheric temperature-after the brooding the stage-
varying from 26 to $36^{\circ} \mathrm{C}$

It has been demonstrated that Vitamin C had a tendency to reduce body temperature in heat stressed birds (Ahmed and Moreng, 1944 and Subaschandran and Balloun 1966). Also grimes and moreng (1965) found the asin S.C. White Leghorn, New Hampshire and depression in body temperature perature levels, $21^{\circ} \mathrm{C}$ and $29^{\circ} \mathrm{C}$. supplementary ascorbic acid was of aider, Thornton (1962) showed that perature of the chickens in either

warm atmosphere.

In heat stressed birds $\left(38^{\circ} \mathrm{C}\right)$ vitamin $\mathrm{C}$ did not affect blood pressure signficantly (Subaschandran and Balloun, 1966).

Accordingly, the following experiment was designed to study the influence of vitamin $C$ supplementation on feed efficiency, growth rate, mortality rate, body temperature, respiration rate, blood pressure and serum calcium and phosphorus in growing Fayoumi chicks up to 12 weeks of age
reared under three variable temperature levels.

\section{Animal and diet}

$$
\text { Experimentai }
$$

600 one-day -old Fayoumi chicks were used. They were reared in finishing batteries from hatch till the 12 th week of age. Electric heating coils thermostatic heater to heat. Also, the brooder was supplied with elcctric as possible during the experim the inside temperature almost constant as far into three groups. Chicks in the first. The chicks were divided randomly high temperature of $90^{\circ} \mathrm{F}$ from the days oroup were brooded under constant The second group was brooded under the hatch until the 12th week of age. system. The temperature started at $90^{\circ} \mathrm{F}$. The routine every week till it reached a constant at $90^{\circ} \mathrm{F}$ then decreased gradually by $3^{\circ} \mathrm{F}$ group were subjected to $75 \mathrm{~F}$ in the second week and $65^{\circ} \mathrm{F}$ from age. Every group was divided int 12 th week of were supplied repectively with $00,50,100$ and subgroups (1-4). The subgroups

ascorbic acid in the ration.

wheat bran, $12 \%$ rice bran, $20 \%$ of $40 \%$ maize, $10 \%$ horse beans, $12 \%$

Egypt. J. Anim. Prod., 15, No. 2 (1975) 
VITAMIN O SUPPLEMENTATION TO GROWING CHICK'S RATIONS 211

meal. The ration was supplemented by $0.5 \%$ common salt, $1 \%$ bone meal, $2 \%$ calcium carbonate and 2 grams feed supplement pfizer vitamin $A+D$, per $\mathrm{kg}$ diet (vitamin A $5000 \mathrm{IU} / \mathrm{g}$. and vitamin $D_{3} 500 \mathrm{IU} / \mathrm{g}$ ). Individual body weight and feed consumption were recorded at bi-weekly intervals. Monthly records for body temperature and respiration rate between 12 noon to 2.00 p.m. were tested in random group samples of 20 chicks. At the end of the experiment, 6 chicks from each subgroup were used to estimate blood pressure by the manometric method (Sturkie, 1954). After measuring blood

pressure, blood samples were collected from the same chicks. The serum of each chick was used for the determination of calcium (Roe and Kahn 1929), and phosphorus (Fiske and Subbarow, 1925).

Statistical analysis were carried out (Steel and Torrie, 1960).

\section{Results and Discussion}

Effect of ascorbic acid on feed consumption and feed efficiency

From Table 1, it is evident that chickens reared from the date of hatch till the 12th week of age under low temperature consumed greater amount of feed, while those reared under high temperature consumed less amount of feed than those reared under normal or low temperature. Similar findings were reported by Muller (1962).

TABLE 1. Average feed consumed (g/individual) at bi-weekly intervals for the different groups treated with ascorbic acid during the growing period

\begin{tabular}{|c|c|c|c|c|c|c|c|c|}
\hline \multirow{2}{*}{ Temp. } & \multirow{2}{*}{$\begin{array}{c}\text { Levels } \\
\text { of } \\
\text { ascorbic } \\
\text { acid } \\
\text { ppm. }\end{array}$} & \multicolumn{7}{|c|}{ Periods in weeks } \\
\hline & & -2 & $2-4$ & $4-6$ & $6-8$ & $8-10$ & $10-12$ & $0-12$ \\
\hline High $90^{\circ} \mathrm{F}$. . & $\begin{array}{r}00 \\
50 \\
100 \\
200\end{array}$ & $\begin{array}{l}116 \\
118 \\
140 \\
128\end{array}$ & $\begin{array}{l}252 \\
235 \\
243 \\
262\end{array}$ & $\begin{array}{l}304 \\
267 \\
262 \\
264\end{array}$ & $\begin{array}{l}327 \\
383 \\
277 \\
271\end{array}$ & $\begin{array}{l}191 \\
568 \\
459 \\
475\end{array}$ & $\begin{array}{l}316 \\
637 \\
599 \\
492\end{array}$ & $\begin{array}{l}1507 \\
2209 \\
1983 \\
1894\end{array}$ \\
\hline $\begin{array}{c}\text { Normal } 90-87 \\
65^{\circ} \mathrm{F} . .\end{array}$ & $\begin{array}{r}00 \\
50 \\
100 \\
200\end{array}$ & $\begin{array}{r}118 \\
119 \\
92 \\
102 .\end{array}$ & $\begin{array}{r}241 \\
218 \\
228 \\
231\end{array}$ & $\begin{array}{l}195 \\
222 \\
219 \\
210\end{array}$ & $\begin{array}{r}325 \\
277 \\
233 \\
331\end{array}$ & $\begin{array}{l}439 \\
417 \\
449 \\
382\end{array}$ & $\begin{array}{l}475 \\
601 \\
482 \\
438\end{array}$ & $\begin{array}{l}1796 \\
1856 \\
1706 \\
1697\end{array}$ \\
\hline $\begin{array}{r}\text { Low } 85-75-650 \\
E\end{array}$ & $\begin{array}{r}00 \\
50 \\
100 \\
200\end{array}$ & $\begin{array}{l}184 \\
161 \\
136 \\
139\end{array}$ & $\begin{array}{r}228 \\
290 \\
289 \\
286\end{array}$ & $\begin{array}{l}261 \\
336 \\
277 \\
261\end{array}$ & $\begin{array}{l}326 \\
365 \\
251 \\
443\end{array}$ & $\begin{array}{l}474 \\
585 \\
407 \\
504\end{array}$ & $\begin{array}{l}598 \\
493 \\
493 \\
640\end{array}$ & $\begin{array}{l}2072 \\
2232 \\
1855 \\
2096\end{array}$ \\
\hline
\end{tabular}

Egypt. J. Anim. Prod., 15, No. 2 (1975) 
Ascorbic acid supplementation to the ration of the growing chicks increased feed consumption (Table 1). The effect of ascorbic acid on feed consumption during the growing period was more pronounced under high temperature than under low or normal temperature.

Feed efficiency for increase in body weight was higher when chickens were reared under normal temperature followed by those reared under low temperature and lastly chicks reared under high temperature (Table 2). Prince et al (1965) came to the conclusion that feed efficiency was significantly lower at $12.6^{\circ} \mathrm{C}$ than at $23.8^{\circ} \mathrm{C}$.

Addition of ascorbic acid to the ration of the growing chicks improved feed efficiency. This improvement was more pronounced under high temperature than under low or normal temperature. Also, the feed conversion was higher under the high level than the low level.

TBLE 2. Feed efficiency at bi-weekly intervals for the different groups treated with ascorbic acid during the grownig period.

\begin{tabular}{|c|c|c|c|c|c|c|c|c|c|c|}
\hline \multirow{2}{*}{\multicolumn{3}{|c|}{ Temp. }} & \multirow{3}{*}{$\begin{array}{c}\begin{array}{c}\text { Level } \\
\text { of } \\
\text { ascorbic } \\
\text { acid } \\
(\mathrm{ppm})\end{array} \\
\\
00\end{array}$} & \multicolumn{6}{|c|}{ Period in weeks } & \multirow{3}{*}{$\begin{array}{l}0-12 \\
4.73\end{array}$} \\
\hline & & & & $0-2$ & $2-4$ & $4-6$ & $6-8$ & $8-10$ & $10-12$ & \\
\hline \multirow{4}{*}{ High } & \multirow{4}{*}{$\cdot \cdot$} & \multirow{4}{*}{$\cdot \cdot$} & & 3.06 & 3.87 & 4.20 & 5.06 & 5.73 & 6.45 & \\
\hline & & & 50 & 2.86 & 3.01 & 3.51 & 4.94 & 5.22 & 531 & 4.14 \\
\hline & & & 100 & 2.78 & 3.07 & 3.23 & 3.42 & 4.57 & 5.13 & 3.70 \\
\hline & & & 200 & 2.94 & 3.32 & 3.24 & 3.41 & 4.12 & 4.17 & 3.53 \\
\hline \multirow{4}{*}{\multicolumn{3}{|c|}{ Normal . }} & 00 & 2.51 & 2.94 & 3.20 & 3.61 & 4.55 & 5.16 & 3.66 \\
\hline & & & 50 & 2.44 & 2.59 & 3.13 & 3.20 & 4. 32 & 5.03 & 3.45 \\
\hline & & & 100 & 1.95 & 2.50 & 2.94 & 3.17 & 3.95 & 4.02 & 3.14 \\
\hline & & & 200 & 2.48 & 2.50 & 2.75 & 3.07 & 3.88 & 3.59 & 3.04 \\
\hline \multirow{4}{*}{ Low } & \multirow{4}{*}{\multicolumn{2}{|c|}{$\cdot \cdot$}} & 00 & 3.60 & 3.67 & 3.89 & 4.29 & 4.76 & 5.17 & 4.23 \\
\hline & & & 50 & 2.96 & 3.16 & 3.67 & 4.11 & 4.54 & 5.09 & 3.92 \\
\hline & & & 100 & 2.54 & 2.90 & 3.27 & 3.98 & 4.39 & 4.77 & 3.64 \\
\hline & & & 200 & 2.70 & 2.75 & 3.16 & 3.99 & 4.11 & 4.21 & 3.48 \\
\hline
\end{tabular}

Egypt. J. Anim. Prod., 15, No. 2 (1975) 
Thornton and Moreng (1959) proposed that ascobic acid had stimulating influence on the thyroid gland. This may in turn improve the feed efficiency. Effect of ascorbic acid on growth Absolute body weight

Average body weights at bi-weekly intervals from hatch to twelve weeks of age are shown in Table 3. Chicks reared under normal temperature gave the best absolute weight followed by those reared under low temperature then those under high temperature. It was shown that body size and weight of birds decrease if the surrounding temperature deviates from the optimal values, mainly due to Ioss of appatite (Kempster, 1938 and Huston et al, 1957).

TABLE 3. Absolute average weights (g/individual) at bi-weekly intervals for the different groups treated with ascorbic ac:d during the growing period.

\begin{tabular}{|c|c|c|c|c|c|c|c|c|}
\hline \multirow{2}{*}{ Temp. } & \multirow{2}{*}{$\begin{array}{c}\text { Levels } \\
\text { of } \\
\text { ascorbic } \\
\text { acid (ppm) }\end{array}$} & \multicolumn{7}{|c|}{ Age Intervals in Weeks } \\
\hline & & 0 & 2 & 4 & 6 & 8 & 10 & 12 \\
\hline . & 00 & 27.2 & 65.4 & 130.5 & 202.9 & 267.6 & 301.0 & 350.2 \\
\hline \multirow[t]{4}{*}{ High . } & 50 & 27.4 & 68.8 & 146.8 & 223.0 & 300.6 & 409.6 & 529.6 \\
\hline & 100 & 24.7 & 75.3 & 154.5 & 235.8 & 317.1 & 417.7 & 534.5 \\
\hline & 200 & 25.1 & 68.7 & 147.9 & 229.6 & 309.2 & 424.6 & 542.6 \\
\hline & 00 & 24.7 & 72.1 & 154.3 & 215.5 & 305.6 & 402.1 & 494.2 \\
\hline \multirow[t]{5}{*}{ NormaI. } & 50 & 24.1 & 72.9 & 157.1 & 228.3 & 314.9 & 411.6 & 531.2 \\
\hline & 100 & 24.7 & 72.2 & 159.6 & 234.4 & 308.1 & 421.9 & 541.9 \\
\hline & 200 & 28.4 & 69.6 & 162.3 & 239.0 & 328.8 & 427.3 & 549.5 \\
\hline & 00 & 27.8 & 79.0 & 131.2 & 198.2 & 274.4 & 374.1 & 489.8 \\
\hline & 50 & 27.4 & 82.0 & 174.0 & 265.5 & 354.3 & 483.3 & 580.2 \\
\hline \multirow[t]{2}{*}{ Low } & 100 & 26.8 & 80.5 & 180.3 & 265.0 & 346.4 & 439.2 & 542.7 \\
\hline & 200 & 24.0 & 75.8 & 179.9 & 262.6 & 373.9 & 496.6 & 606.1 \\
\hline
\end{tabular}

Ascorbic acid supplementation to the ration of growing chicks from the date of hatch till 12the week of age improved absolute body weight. At 4 and 8 weeks the increase in absolute body weight was higher in chicks reared 
under low temperature than those reared under high or normal temperature. Meanwhile, at 12 weeks the effect of ascorbic acid was more pronounced when chicks were reared under high than low or normal temperature.

Comparing between the effect of the different levels of ascorbic acid, at 4 weeks of age, the level of a 100 in the ration gave the best results in body weight than the low or high level $(50$ and $200 \mathrm{ppm})$. While, at 8 and 12 weeks the high level $(200 \mathrm{ppm})$ produced the higher body weight. Concerning the effect of ascorbic acid on body weight in hot environment, our results are in agreement with Thernton and Moreng (1958b) and Edrise (1973).

Statistical differences between average body weights at 4,8 and 12 weeks of age for variable treatments of temperature and vitamin levels showed highly significant differences (Table 4). Also, highly significant differences were obtained for interactions of levels and temperature treatments at 12 weeks. The significant interaction between various levels and temperature indicate the importance of the suitability of variable levels of ascorbic acid to different temperature.

TABLE 4. Analysis of variance of absolute body weights at 4,8 and 12 weeks of age for the different groups treated with ascorbic acid.

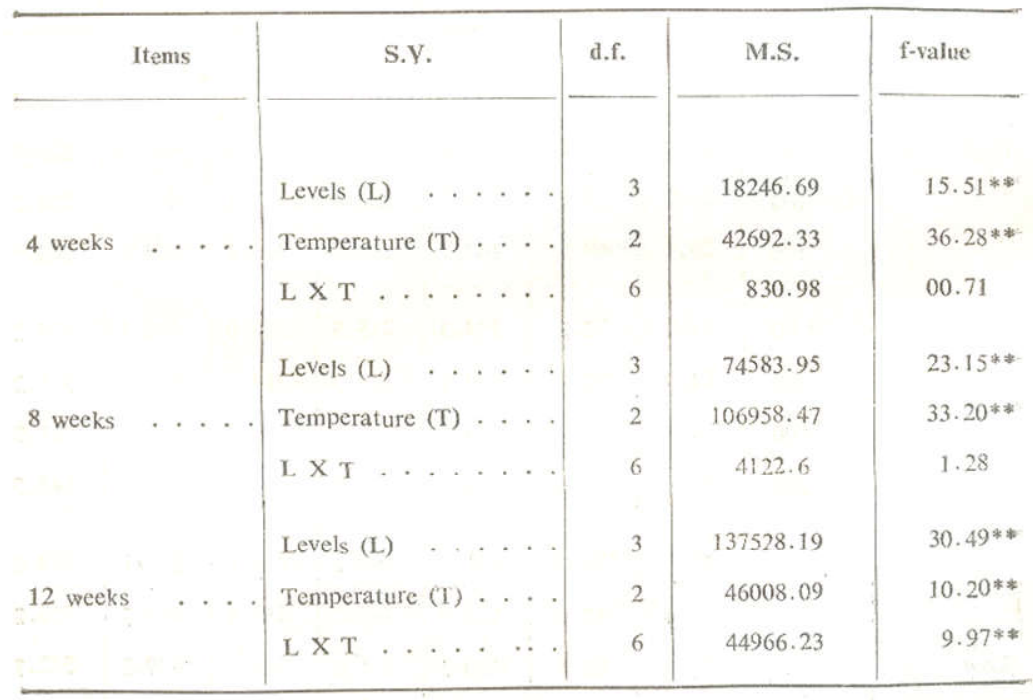

$* * \mathrm{P}<0.01$

Relative rate of growth

It is apparent from Table (5) that birds grew initially faster then tended to slow down by advancing age. The relative increase in rate of growth during the early periods of life (0-4 weeks) in group reared under normaly temperature

Egypt. J. Anim. Prod., 15, No. 2 (1975) 
is well illustrated as compared to groups reared under high or low temperature. Nevertheless, the attempt of groups to increase their rate of growth at ater ages (4-12 weeks) was apparent for the group reared under low temperature.

TABLE 5. Relative rate of growth at bi-weekly intervals for the different groups treated with ascorbic acid during the growing period.

\begin{tabular}{|c|c|c|c|c|c|c|c|c|}
\hline & \multirow{2}{*}{ Temp. } & \multirow{2}{*}{$\begin{array}{l}\text { Levels of } \\
\text { ascorbic } \\
\text { (ppm) }\end{array}$} & \multicolumn{6}{|c|}{ Periods in weeks } \\
\hline & & & 0.2 & $2-4$ & $4-6$ & $6-8$ & $8-10$ & $10-12$ \\
\hline \multirow{4}{*}{ High } & & 00 & 82.5 & 66.5 & 43.4 & 27.5 & 11.8 & 15.1 \\
\hline & $\ldots$. & 50 & 85.9 & 72.4 & 41.2 & 29.6 & 30.7 & 25.6 \\
\hline & & 100 & 101.1 & 69.0 & 41.7 & 29.4 & 27.4 & 35.0 \\
\hline & & 200 & 93.0 & 73.1 & 43.3 & 29.8 & 31.5 & 24.4 \\
\hline \multirow{4}{*}{ Normal } & & 00 & 97.9 & 72.6 & 33.2 & 34.6 & 27.3 & 20.6 \\
\hline & $1 \ldots$ & 50 & 100.7 & 73.3 & 36.9 & 31.9 & 26.6 & 25.4 \\
\hline & & 100 & 98.1 & 75.5 & 37.9 & 27.2 & 31.2 & 24.9 \\
\hline & & 200 & 84.0 & 80.0 & 38.2 & 31.7 & 26.1 & 25.0 \\
\hline \multirow{4}{*}{ Low } & & 00 & 95.9 & 59.2 & 40.7 & 32.2 & 30.7 & 26.8 \\
\hline & $\cdots \cdot$ & 50 & 99.9 & 71.8 & 41.7 & 28.7 & 30.8 & 18.2 \\
\hline & & 100 & 100.1 & 76.5 & 38.0 & 26.6 & 23.6 & 21.1 \\
\hline & & 200 & 103.8 & 81.5 & 37.4 & 35.0 & 28.2 & 19.9 \\
\hline
\end{tabular}

Under different temperatures the addition of ascorbic acid to the ration increased the relative growth rate from hatch till the fourth week of age, (Table 5). From 4-12 weeks of age, the addition of ascorbic acid under low temperature decreased the relive growth rate while under high or normal temperature it increased the relative rate of growth.

Effect of ascorbic acid on physiological reactions

From Table 6 , it can be noted that high temperature caused an increase in body temperature and respiration rate of the chicks, while low temperature decreased their bo fy tumperature and respiraton rate. The body temperature of pullets rises whenever the environmental temperature exceeds $26.6^{\circ} \mathrm{C}$. (Wilson, 1948). Baldwin and Kendeigh (1932). Thornton (1961a) 
and Yeates et al. (1941) found that at air temperature of $32.2{ }^{\circ} \mathrm{C}$ the cloacal temperature of the birds begins to increase above the normal.

Addition of ascorbic acid to the ration of growing chicks from date of hatch till the 12th week of age decreased body temperature under different temperatures, while the respiration rate was increased under high and normal and decreased under low temperature (Table 6). The average reductions in in body temperature (compared to untreated groups) were $4.7,1.8$ and $2.7^{\circ} \mathrm{C}$. in the groups reared under high, low and normal temperatures respectivelye The effect of ascorbic acid on body temperature and respiration rate mor pronounced under the higher levels than the lower levels of environmental temperature. The differences were highly significant (Table 8).

T $4 B L E$ 6. Average body temveraturs, respiration rate and blood pressure for the difforent groups treated with ascorbic acid during the growing period.

\begin{tabular}{|c|c|c|c|c|}
\hline Temp. & $\begin{array}{l}\text { Levels of } \\
\text { ascorbic } \\
\text { acid (ppm) }\end{array}$ & $\begin{array}{l}\text { Body temp. } \\
\text { ('م) }\end{array}$ & $\begin{array}{c}\text { Respiration } \\
\text { rate } \\
(\quad / \text { minute })\end{array}$ & $\begin{array}{l}\text { Biood pressure } \\
(\mathrm{mm} \mathrm{Hg})\end{array}$ \\
\hline \multirow{4}{*}{ High . . . . } & 00 & 112.3 & $141 \cdot 3$ & 118.7 \\
\hline & 50 & 108.2 & 148.0 & 118.6 \\
\hline & 100 & 107.3 & 153.0 & 117.9 \\
\hline & 200 & 107.3 & 162.8 & 116.8 \\
\hline \multirow{3}{*}{ Normal . . . } & 00 & 110.7 & 69.2 & 117.9 \\
\hline & 50 & 109.2 & 75.7 & 116.8 \\
\hline & 100 & 107.9 & 79.5 & 117.7 \\
\hline \multirow{5}{*}{ Low ..... } & 200 & 107.1 & 89.8 & 116.8 \\
\hline & 00 & 107.7 & 63.9 & 117.5 \\
\hline & 50 & 106.6 & 53.3 & 117.4 \\
\hline & 100 & 105.9 & 57.8 & 117.7 \\
\hline & 200 & 105.3 & 56.4 & 116.6 \\
\hline
\end{tabular}

Addition of ascorbic acid to the ration of growing chicks showed no significant effect on blood pressure under different environmental temperatu re (Tables 6 and 8).

Egypt. J. Anim. Prod., 15, No. 2 (1975) 
These results are in good agreement with several authors such as Grimes and Moreng, 1965 : and Subaschandran and Balloun, 1966.

Effect of ascorbic acid on serum calcium and phosphorus

High temperature had highly significant effect on decreasing the levels of serum calcium and phosphorus (Table 7). This result is in agreement with Conrad (1939) who found that serum calcium levels were reduced at high
temperatures.

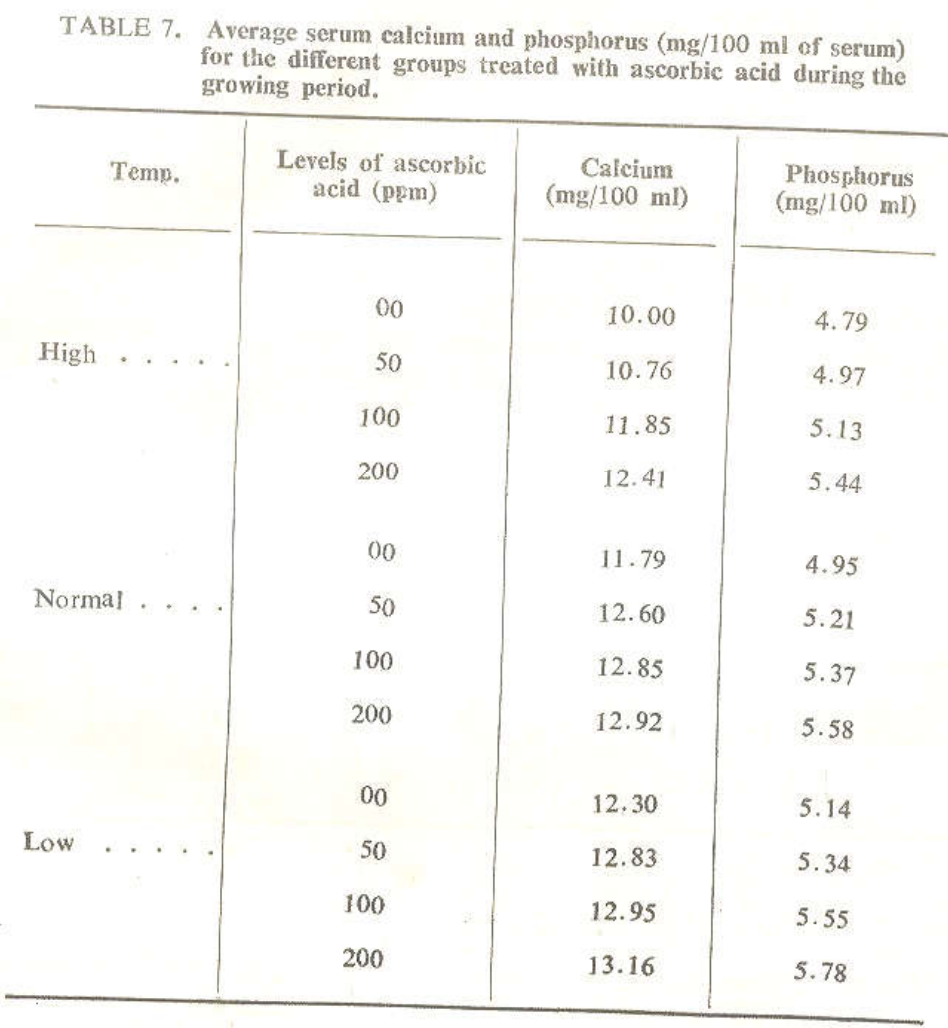

Addition of ascorbic acid to the ration of the growing chicks increased the serum calcium and phosphorus. This effect was more pronounced under high temperature than low or normal temperature (Table 7). The differences were highly significant (Table 8). The high level of ascorbic acid supplementation caused greater increase in serum calcium and phosphorus than
the low level. 
TABLE 8. Analysis of variance of body temperature, respiration rate, blood pressure and serum calcium and phospherature, respiration rate, blood pressurs ascorbic acid during the grwing period.

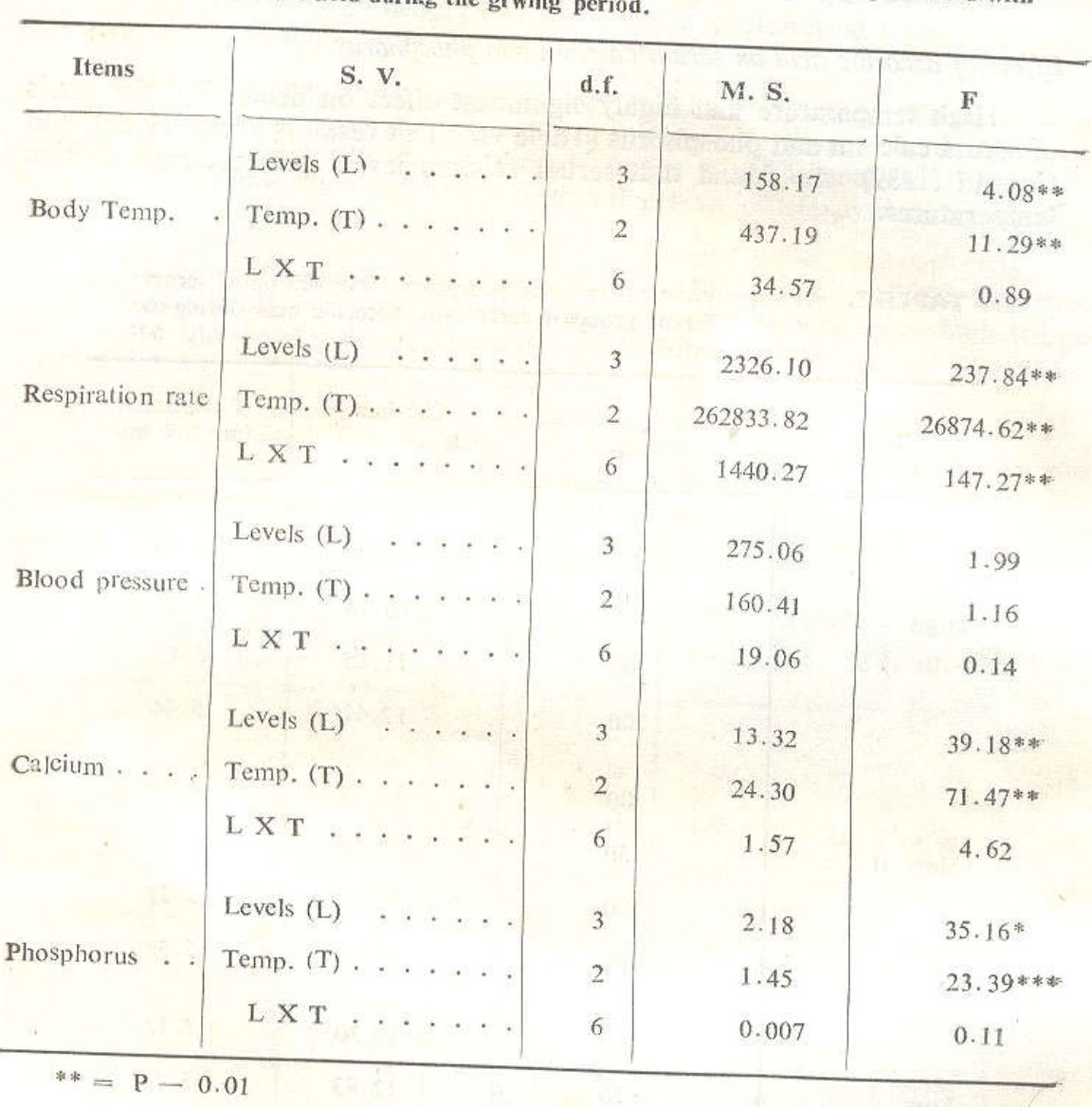

Effect of ascorbic acid on mortality rate

Mortality rate increased when chicks were reared under high or low temperature with or without ascorbic acid than those reared under normal temperature (Table 9). As far as high temperature is concerned, our findings are
supported by those of Muller (1962).

Ascorbic acid supplementation to the ration of growing chicks decreased the mortality rate (Table 9), by $12.7,10.7$ and $6.7 \%$ for chicks reared under high, low normal temperatures respectively. The higher levels of ascorbic acid caused greater reduction in mortality than the lower level. Our results are similar to those obtained by Edrise (1973).

Egypt. J. Anim. Prod., 15, No. 2 (1975) 
TABLE 9. Mortality rate for the different groups treated with ascorbic acid during the growing period.

\begin{tabular}{c|c|c|c}
\hline $\begin{array}{c}\text { Levels of } \\
\text { ascorbic } \\
\text { acid (ppm) }\end{array}$ & Mortality \% \\
\hline High temp. & Normal tomo. & Low temp. \\
\hline 00 & 24 & 14 & 22 \\
50 & 18 & 10 & 16 \\
100 & 14 & 6 & 10 \\
200 & 6 & 4 & 9 \\
\hline
\end{tabular}

From the previous results and discussion we can conclude stressed birds, the addition of vitamin $\mathrm{C}$ to we can conclude that, in heat the disastrous effect of the heat stress concerning the ration countreacting rate, serum calcium and phosphor concerning the feed efficiency, growth effect of ascorbic acid supplementation was acourtity rate. This beneficial taining the normal physiological activities quired through its role in mainrate and blood pressure) against the heat stress.

\section{Refierences}

temperature environments as influenced by ase dietary ascorbi acid under high Baidwin, S.P. and Ketdeigh S.C. (1932) Phy tific Publication Cleveland Museum of Conrad, R.M. (1939) The effect of hioh tempratur History, 3, 196.

Poul. Sci, 18, 327 .

Edrise, B.M. (1973) Stuties of the effert of supple Con growth Performunce of "Dokki 4 " chicis. M.V. Sc. Thesis, Fac. Vet. Med. Cairo
University.

Fiske, C.H. and Subbarow Y. (1925) J. Biol. Chem. $\mathbf{6 6}, 375$.

phosphorus. in purified chick rations. Poul. Sci. 38,533 .

Grimes, G.R., and Moreng, R.F. (1965) Bogy icmo ental temperature and ascorbic acid. Poul. Sci. $\mathbf{4 4 , 1 3 7 4}$. 137 sody to breed, environm Huston, T.M., Joiner, W. P. and Carmen, J.L. (1957) Breed 1374

of domestic fowl held at high environmental temperatured diffences in egg prodution

$$
\text { Egypt. J. Anim. Prod., 15, No. } 2 \text { (1975) }
$$


Kempster, H.L. (1938) The influence of summer temperatures on the rate of growth of chickens. Poul. Sci., 17, 259.

Muller, W.J. (1962) "Animal and Poultry Production", p. 67. College of Agric. stat Univ, New Brunswick, New Jersey.

Prince, R.P., Nlitaker, Mutterson, J.H., and Luginbuhl, R.E. (1965) Response of chicken to temperature and relative humidity environments. Poult. Sci., 44, 73.

Roe, C. and Khan, X. (1929) The colorimetric determination of calcium. J. Biol. Chem. $81,1$.

Steel, R.G.D. and Torrie, J.H. (1960) "Principles and Procedures of Statistics". McGraw Hill Book Company Inc., New York.

Sturkie, P.D. (1954) "Avian Physiology". pp" 118-13. Comstock publishing associates. Ithaca, New York.

Subaschandran, D.V and Balloun, S.L. (1966) Acetyl-P aminophenol and vitamin $\mathrm{C}$ in heat stressed birds' Poul. Sci., 46, 1073.

Thornton, P.A. $(1959$ b) The response of dietary protein level on the response of Sci. W.L. to supplementary ascorbic acid. Poul. Sci., 39, 1072.

Thornton, P.A. (1961 a) Environmental temperature influence on the body temperature of the ihicken. Poul. Sci., 40, 1464.

Thornton, P.A. (1962) The effect of environmental temperature on body temperature of oxygen uptake by the chicken. Poul. Sci., 41, 1053.

Thornton, P.A. and Moreng, R.E. $(1958$ b) The effect of ascorbic acid in the diet of the laying hen. Poul. Sci., 3r, 1248.

Thornton, P.A. and Moreng, R.E. (1959) Further evidence on the value of ascorbic acid of maintenance of shell quality in warm environmental temperature. Poul. Sci., 36, 594

Wilosn, W.O. (1948) Some effects of increasing environmental temperatures on pullets Poul. Sci. 28, 813.

Yeats, N.TIM., Lee, D.H.K. and Hires, H.J·O. (1941) Reactions of domestic fowls to hot atmospheres. Proc, Roy. Soc. Queensland, 53, 105. (c.f. King J.R. and Farner. D.S 1964).

Egypt. J. Anim. Prod., 15, No. 2. (1975) 
VITAMIN O SUPPLEMENTATION TO GROWING CHICK'S RATIONS 221

$$
\begin{aligned}
& \text { ثأثير اعطاء فيتامين ج على التنثليم العرارى للكتاكيت الثامية } \\
& \text { متحمل جمال الدين قهر } 6 \text { مختار عبد الفتاح } 6 \text { أسمامة عز الدين معمد ومحمد } \\
& \text { متمود الثنافعى الثمال الثن } \\
& \text { قسم الانتاج الجهيوانى ، كلية الزرواعة ، جامعة القاهرة }
\end{aligned}
$$

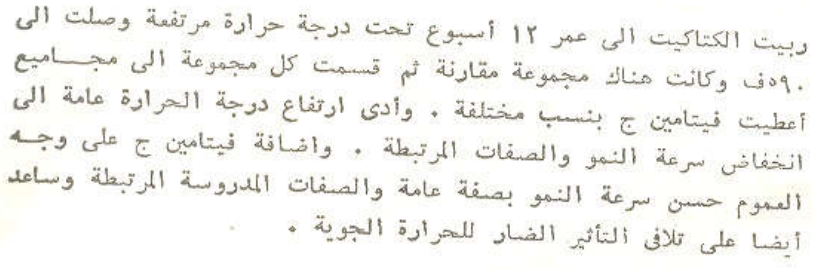

